\title{
MELACAK MAQHASHID NIKAH DALAM PERSETUJUAN CALON MEMPELAI WANITA DALAM PERKAWINAN DI INDONESIA
}

\author{
Moh. Dliya'ul Chaq \\ Institut Agama Islam Bani Fattah Tambakberas Jombang \\ Email: yayakrafi@gmail.com
}

\begin{abstract}
In the science of fiqh it is explained that asking permission for a woman's consent in the marriage to the girl is not a widow, because the widow knows more about herself and is experienced in navigating domestic life, permission of a virgin (girl) only by silence because girls feel ashamed to be frank Meanwhile, approval of a widow with clear words from her, if a girl is silent or smiling and does not cry or cry sadly, then it is a sign of her agreement to get married. A woman's approval will be directly related to the feeling of a girl who will accompany her husband for life, he will undergo and will feel happiness and peace in his household, so asking for the approval of a girl and widow in marriage is highly recommended, because the purpose of marriage (Maqhashid al-nikah) is to form a family that sakinah mawaddah warahamah..
\end{abstract}

Keyword: permission, women, purpose of marriage.

\section{Pendahuluan}

Manusia sebagai makhluk sosial yang diciptakan oleh Allah untuk hidup berpasang-pasangan, saling mengisi dan bekerjasama antara satu dan lainnya yang diwujudkan dalam perkawinan akan membentuk sebuah keluarga yang merupakan suatu persekutuan terkecil dalam masyarakat. Dalam Kompilasi Hukum Islam dijelaskan bahwa perkawinan merupakan sebuah ikatan lahir batin yang sangat agung antara suami dan istri (mithäqan ghalidan) untuk mentaati perintah Allah dan melaksanakannya merupakan ibadah. ${ }^{1}$ Sedangkan tujuan perkawinan sendiri adalah untuk mewujudkan sebuah keluarga yang sakinah,

\footnotetext{
${ }^{1}$ Kompilasi Hukum Islam Pasal 2.
} 
mawaddah dan rahmah sebagai salah satu sarana ibadah kepada Allah SWT. ${ }^{2}$ Sebagaimana firman Allah QS. Al-Nisa' (4):1

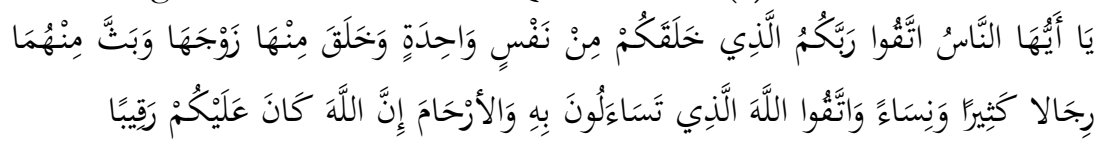

"Hai sekalian manusia, bertakwalah kepada Tuhan-mu yang Telah menciptakan kamu dari seorang diri, dan dari padanya Allah menciptakan isterinya; dan dari pada keduanya Allah memperkembangbiakkan laki-laki dan perempuan yang banyak, dan bertakwalah kepada Allah yang dengan (mempergunakan) nama-Nya kamu saling meminta satu sama lain, dan (peliharalah) hubungan silaturrahim. Sesungguhnya Allah selalu menjaga dan Mengawasi kamu".

Di samping itu, perkawinan juga merupakan sunnah Rasul yang pernah dilakukannya selama hidupnya dan menghendaki umatnya berbuat yang sama. ${ }^{4} \mathrm{Hal}$ ini terdapat dalam hadis yang berasal dari Anas bin Malik, sabda Nabi yang bunyinya:

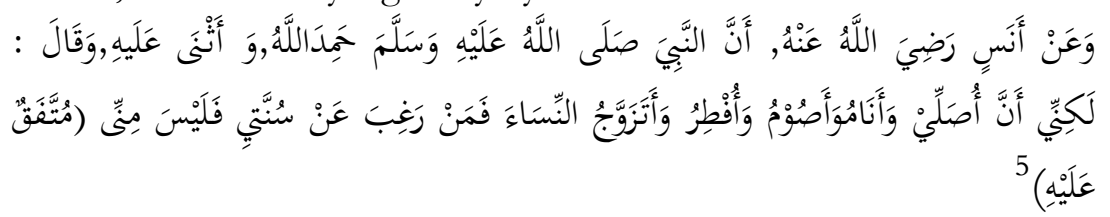

"Dari Anas Ibnu Malik Radbiyallabu 'anbu bahwa Nabi Sallallabu 'alaibi wa sallam, setelah memuji dan Allah dan menyanjung-Nya bersabda: "Tetapi aku sholat, tidur, berpuasa, berbuka, dan mengawini perempuan. Barangsiapa membenci sunnahku, ia tidak termasuk umatku."”

Perkawinan merupakan amanah Allah SWT, untuk menyempurnakan amanah itu ada beberapa rukun yang harus dipenuhi dalam perkawinan, dari beberapa rukun dalam perkawinan yang sangat penting adalah calon mempelai dan wali, akan tetapi salah satu isu penting yang sering timbul dan menjadi bahan perbincangan dalam masyarakat kita ialah bidang kuasa wali atau dalam Fiqh disebut hak Ijbar, yaitu suatu tindakan untuk melakukan sesuatu atas dasar tanggungjawab. Istilah Ijbar dikenal dalam fiqh Islam dalam kaitannya dengan soal

\footnotetext{
${ }^{2}$ Kompilasi Hukum Islam Pasal 1-2.

3 Al-Qur'an danTafsirannya (Jakarta: Lentera Abadi, 2010), Jus 2, hlm. 110

${ }^{4}$ Amir Syarifuddin, Hukum Perkawinan Islam di Indonesia: Antara Figh Munakahat dan Undang-Undang Perkawinan (Jakarta: Prenada Media, 2006), 43.

${ }^{5}$ Ibnu Hajar al-Asqalani, Bulughul Maram (Mesir: al-Matba'ah Salafiyyah, t.th) 195.
} 
perkawinan. Dalam fiqh mazhab Syâfi'î orang yang memiliki kekuasaan atau hak Ijbar adalah ayah atau (kalau tidak ada), kakek. Jadi, apabila seorang ayah dikatakan sebagai wali mujbir, maka dia adalah orang yang mempunyai kekuasaan atau hak untuk mengawinkan anak perempuannya, meskipun tanpa persetujuan dari pihak yang bersangkutan, dan perkawinan ini dipandang sah secara hukum islam. Hak Ijbar dimaksudkan sebagai bentuk perlindungan atau tanggungjawab ayah terhadap anaknya, karena keadaan dirinya (anak) yang dianggap belum/tidak memiliki kemampuan atau lemah untuk bertindak. ${ }^{6}$

Berbanding terbalik dengan tujuan hak Ijbar di atas muncul wacana yang berkembang berkembang di masyarakat saat ini bahwa wali mujbir dimaknai sebagai orang tua yang memaksa anaknya untuk menikah dengan pilihan orang tua, sehingga masyarakat kita masih ada yang mentradisikan serta menyamakan "kawin paksa" yang konotasinya identik dengan "Ikrah" dengan hak Ijbar. Ikrah sendiri adalah suatu paksaan terhadap seseorang untuk melakukan sesuatu pekerjaan tertentu dengan suatu ancaman yang membahayakan terhadap jiwa atau tubuhnya, tanpa dia sendiri mampu melawannya. Sementara bagi orang yang dipaksa, perbuatan tersebut sebenarnya bertentangan dengan kehendak hati nuraninya atau pikirannya. ${ }^{7}$

Dari pengertian ini telah didapati adanya perbedaan konsep yang jelas antara hak Ijbar dan Ikrah. Dalam ilmu fiqh dijelaskan bahwa meminta izin untuk persetujuan seorang perempuan dalam perkawinan itu terhadap gadis bukan janda, sebab janda lebih tahu atas dirinya dan berpengalaman dalam mengarungi kehidupan rumah tangga, izin seorang perawan (gadis) hanya dengan diamnya karena anak gadis merasa malu untuk berterus terang, sedangkan persetujuan terhadap seorang janda dengan perkataan yang jelas darinya, jika seorang gadis diam atau tersenyum dan tidak berteriak atau menangis sedih maka itu tanda persetujuan darinya untuk melangsungkan perkawinan. ${ }^{8}$

Dalam ilmu fiqh dijelaskan bahwa meminta izin untuk persetujuan seorang perempuan dalam perkawinan itu terhadap gadis bukan janda, sebab janda lebih tahu atas dirinya dan berpengalaman dalam mengarungi kehidupan rumah tangga, izin seorang perawan (gadis) hanya dengan diamnya karena anak gadis merasa malu untuk berterus terang, sedangkan persetujuan terhadap seorang janda dengan

\footnotetext{
${ }^{6}$ Wahbah Zuhayli, Al-Figh al-Islami Wa Adillatubu (Beirut: Dar al-Fikr: 1997), jus 9, hlm. 6691

${ }^{7}$ Husein Muhammad, Figh Perempuan (Yogyakarta: LKiS, 2001), hlm. 106

${ }^{8}$ Wahbah Zuhayli, Al-Figh al-Islami Wa Adillatubu (Beirut: Dar al-Fikr: 1997), Jus 7, hlm. 212-213
} 
perkataan yang jelas darinya, jika seorang gadis diam atau tersenyum dan tidak berteriak atau menangis sedih maka itu tanda persetujuan darinya untuk melangsungkan perkawinan. ${ }^{\text {' }}$

Persetujuan wanita akan berkaitan langsung dengan perasaan seorang gadis yang akan mendampingi suaminya seumur hidup, dialah yang akan menjalani dan akan merasakan kebahagiaan serta ketentraman dalam rumah tangganya, maka meminta persetujuan seorang gadis dan janda dalam perkawinan sangatlah dianjurkan, sebab seorang perempuan memiliki hak untuk menentukan pilihannya, seperti dalam hadits Nabi Saw:

$$
\begin{aligned}
& \text { لا تنكح الأيم حتى تستأمر ولا تنكح البكر حتى تستأذن قالوا يا رسول الله وكيف اذها؟ }
\end{aligned}
$$

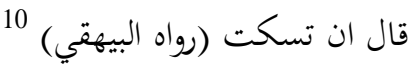

"Tidak boleh dinikahkan para janda sehingga ia diajak musyawarah dan tidak boleh dinikahkan seorang gadis sehingga dimintai izinnya, mereka bertanya, ya Rasulullah bagaimana dengan izinnya? Rasulullah menjawab: diamnya."

$$
\begin{aligned}
& \text { عن خنساء بنت خدام الأنصاري أن اباها زوجها وهي ثيب فكرهت ذلك فأتت رسول } \\
& 11 \text { الله ص.م فرد نكاحها (رواه البخاري) }
\end{aligned}
$$

"Dari Khansa binti Khidam sesungguhnya bapaknya telah mengawinkannya, sedang Khansa adalah seorang janda, maka ia datang menghadap Rasulullah Saw maka Rasulullah menolak (membatalkan) nikahnya."

Al-Syafi'i, al-Maliki dan al-Hambali berpendapat bahwa jika wanita yang baligh dan berakal sehat itu masih gadis, maka hak mengawinkan dirinya ada pada wali. Akan tetapi jika dia janda maka hak itu ada pada keduanya, wali tidak boleh mengawinkan wanita janda itu tanpa persetujuannya. Sebaliknya wanita itupun tidak boleh mengawinkan dirinya tanpa restu sang wali. Namun, pengucapan akad adalah hak wali. Akad yang diucapkan hanya oleh wanita tersebut tidak berlaku sama sekali, walaupun akad itu sendiri memerlukan persetujuannya. ${ }^{12}$

Sementera itu, al-Hanafi mengatakan bahwa wanita yang telah baligh dan berakal sehat boleh memilih sendiri suaminya dan boleh pula

\footnotetext{
${ }^{9}$ Ibid, Jus 7, hlm. 212-213

${ }_{10}$ Ahmad Ibn Husein al-Baihaqi, Sunan al-Baihaqi al-Kubra (Maktabah Syamilah), Jus 7, hlm. 122

${ }^{11}$ Al-Bukhari, Sahih Al- Bukhori (Beirut: Dar al-Fikr), Juz 6, Nomor 5138

12 Muhammad Jawad Mughniyah, Fiqh Lima Mazhab, Ja'fari, Hanafi, Maliki, Syafi'I, Hambali (Jakarta: Lentera, 2000), hlm. 345
} 
melakukan akad nikah sendiri, baik dia perawan maupun janda. Tidak ada seorangpun yang mempunyai wewenang atas diri perawan maupun janda. Tidak ada seorangpun yang mempunyai wewenang atas dirinya atau menentang pilihannya, dengan syarat, orang yang dipilihnya itu sekufu (sepadan) dengannya dan maharnya tidak kurang dari dengan mahar mitsil, tetapi bila dia memilih seorang laki-laki yang tidak sekufu dengannya, maka walinya boleh menentangnya, dan meminta kepada qadhi untuk membatalkan akad nikahnya. Kalau wanita tersebut kawin dengan laki-laki lain dengan mahar kurang dari mahar mitsil, qadhi diminta membatalkan akadnya bila mahar mitsil tersebut tidak dipenuhi oleh suaminya. ${ }^{13}$ Sedangkan menurut mayoritas Ulamah Imamiyah berpendapat bahwa seorang wanita baligh dan berakal sehat, disebabkan oleh kebalighan dan kematangannya itu, berhak bertindak melakukan segala bentuk transaksi dan sebagainya, termasuk juga dalam perkawinan baik dia masih perawan maupun janda. ${ }^{14}$

Dari sini dapat diketahui adanya perbedaan antara ulama terkait dengan penetapan persetujuan calon mempelai wanita terhadap pernikahan yang akan dijalani, dan permasalahan ini oleh penulis masih dipandang relevan dan masih banyak dibahas oleh masyarakat, Sehingga penulis merasa perlu untuk mengkaji ulang teori-teori yang telah dikemukakan oleh para ulama dengan dikomparasikan dengan keadaan sosial hukum di Indonesia.

Sebagai sebuah penelitian akademik, perlu dilakukan penelusuran terhadap penelitian ataupun literatur yang berkaitan dengan masalah yang sedang penulis teliti, diantaranya adalah Artikel berjudul Peranan Wali Dalam Perkawinan Menurut Islam, yang ditulis oleh Abdul Aziz Medan Dosen Fakultas Adab IAIN Sunan Ampel Surabaya tahun 2005 yang merupakan research report membahas tentang peranan wali seutuhnya, dan yang menjadikan beda adalah skripsi ini tidak menyinggung sama sekali tentang persetujuan wanita yang mana persetujuan wanita menjadi titik fokus penelitian ini.

Selain itu, Skripsi berjudul Persetujuan Anak Gadis Sebagai Syarat Sah Perkawinan Dalam Pandangan Ibn Qayyim Al-Jawriyyah, yang ditulis oleh Rety Bilkis Syam Mahasiswa Mahasiswa IAIN Syekh Nurjati Cirebon tahun 2017, skripsi ini mengangkat tentang pemikiran Ibn Qayyim dalam menetapkan persetejuan anak gadis sebegai syarat sah terjadinya perkawinan.

Penelitian ini sendiri bersifat kualitatif, dengan pendekatan melalu studi lapangan dan studi pustaka, objek yang menjadi kajian penelitian

\footnotetext{
${ }^{13}$ Ibid.

${ }^{14}$ Ibid, hlm. 346
} 
adalah Melacak Maqhoshid Nikah Dalam Persetujuan Calon Mempelai Wanita.

\section{Pembahasan \\ Pengertian Perkawinan}

Perkawinan menurut ulama Hanafiyyah secara bahasa bermakna musytarak (مشترك) antara al-wat' (عقد)), ada juga yang mengatakan hakikinya pada akad (عقد) dan makna mająnya pada al-wat' (الوطء), ada juga yang mengatakan sebaliknya, yaitu hakikinya pada al-wat' (الوطء) dan majaznya pada akad (عقد). Akan tetapi pengarang kitab fath alqadir mengatakan bahwa sesungguhnya makna dari perkawinan adalah aldlom (الضم), ${ }^{15}$ yang mana makna dari al-dlom (الضم) dalam Kamus Kontemporer Arab Indonesia adalah mengumpulkan, menggabungkan, menghimpun, ${ }^{16}$

Dengan demikian, makna perkawinan pastilah mengandung salah satu dari dari ketiga makna tersebut yaitu الضم , الوطء, عقد. Pemaknaan tersebut terbukti dalam definisi ulama Hanafiyah tentang perkawinan yang mengatakan:

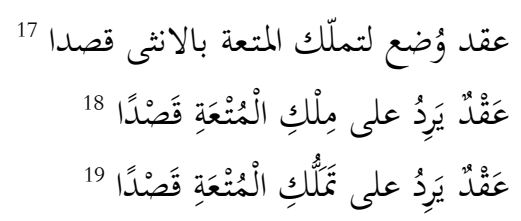

"Nikah adalah akad yang memberikan faedah (mengakibatkan) kepemilikan untuk bersenang-senang secara sadar (sengaja) bagi seorang pria dengan seorang wanita."

Sedangkan pengertian Perkawinan dalam Undang-undang Perkawingan tahun 1974 adalah:

\footnotetext{
${ }^{15}$ Kamaluddin Muhammad Ibn Abdul Wahid, Fath al-Qadir (Maktabah Syamilah), jus 6 hlm. 261

16 Atabik Ali, Kamus Kontemporer Arab Indonesia, cetakan 9 (Yogyakarta: Multi Karya Grafika), hlm. 1211

${ }^{17}$ Kamaluddin Muhammad Ibn Abdul Wahid, Syarb Fath al- Qadir (Maktabah Syamilah), Jus 3, hlm. 186

${ }^{18}$ Syaikh Nidham, Al-Fatawa al-Hindiyah (Maktabah Syamilah), Jus 1, hlm. 267

${ }^{19}$ Fakhruddin Usman, Tabyin al-Haqaiq (Maktabah Syamilah), Jus 2, hlm. 94
} 
"Ikatan lahir batin antara seorang pria dengan wanita sebagai suami isteri dengan tujuan membentuk keluarga yang bahagia dan kekal berdasarkan Ketuhanan Yang Maha Esa."20

Pengertian ini menurut sebagian pakar hukum merupakan penyeragaman unik dengan menghargai adanya variasi berdasarkan agama dan kepercayaan yang Berketuhanan Yang Maha Esa. Pencantuman berdasarkan Ketuhanan Yang Maha Esa itu karena Indonesia berlandaskan Pancasila yang sila pertamanya adalah Ketuhanan Yang Maha Esa. ${ }^{21}$ Salah satu tujuan prinsipil perkawinan adalah membentuk keluarga yang bahagia dan kekal. Untuk itu, pasangan suami istri harus saling membantu dan melengkapi agar dapat mengembangkan kepribadian dalam rangka mencapai kesejahteraan spiritual dan material. ${ }^{22}$ Sebagai sarana dalam mencapai tujuan perkawinan ini maka dibutuhkanlah persetujuan dari kedua mempelai untuk menjalani perkawinan tersebut.

Dalam merumuskan perundang-undangan tentang perkawinan yang digunakan secara umum bagi masyarakat Islam di Indonesia, para perumus terlihat sangat memperhatikan beberapa asas-asas atau prinsipprinsip dalam perkawinan. Asas-asas tersebut adalah:

Pertama, Asas Sukarela maksudnya adalah bahwa perkawinan harus didasarkan atas persetujuan kedua calon mempelai tanpa unsur paksaan.

Kedua, Asas Partisipasi Keluarga yaitu bahwa Undang-Undang Perkawinan di dunia Islam tetap mempertahankan asas keterlibatan atau partisipasi aktif keluarga dalam perkawinan. Penetapan keharusan ada wali dalam pelaksanaan suatu akad, baik dalam konteks hukum Islam maupun Undang-Undang Perkawinan Islam, membuktikan arti penting dari asas partisipasi keluarga ini. Demikian pula dengan keharusan ada izin dari wali terutama bagi anak yang belum mencapai usia nikah, disamping keharusan ada saksi dalam setiap penyelenggaraan akad nikah. ${ }^{23}$

Ketiga, Asas Perceraian Dipersulit asas ini ada bahwa mayoritas perceraian akan merugikan rumah tangga itu sendiri terutama bagi anak-anak dan kaum perempuan.

20 Pasal 1 Undang-undang Republik Indonesia Nomor 1 Tahun 1974 Tentang Perkawinan

21 Amiur Nuruddin dan Azhari Akmal Tarigan, Hukum Perdata Islam (Jakarta: Prenada Media, 2004), hlm. 43

${ }^{22}$ Ahmad Rofiq, Hukum Islam di Indonesia,(Jakarta: Raja Grafindo Persada,1997), hlm. 56

${ }_{23}$ Muhammad Amin Summa, Hukum Keluarga Islam Di Dunia Islam (Jakarta: PT Raja Graffindo Persada, 2005), hlm. 175 
Keempat, Asas Monogami, yakni asas yang hanya memperbolehkan seorang laki-laki mempunyai satu isteri pada jangka waktu tertentu. Menurut Profesor Marcel A. Boisard dalam buku Muhammad Amin Summa sifat khas dari Islam adalah berusaha melegalisir sesuatu hal secara realistis dan tidak mimpi dalam idealisme, yaitu dengan memperhitungkan watak manusia. Dan pada akhirnya moral Islam menghendaki hal yang terhormat. Dalam kehidupan seks misalnya, hal ini hanya dapat terlaksana dengan perkawinan, termasuk perkawinan poligami. Sementara pada saat yang bersamaan, tidak sedikit orang yang mencaki-maki poligami bahkan mengharamkannya dengan dalih kepercayaan agama, tapi dalam praktik melakukan hubungan seksual secara gelap dengan oran lain. Praktik perselingkuhan dan prostitusi yang disinyalir banyak dilakukan orang yang alim sekalipun, mengisyaratkan kondisi yang tidak fair itu. ${ }^{2}$

Kelima, Asas Kedewasaan Calon Mempelai, Maksudnya, undangundang perkawinan menganut prinsip bahwa setiap calon suami dan calon isteri yang hendak melangsungkan akad pernikahan, harus benar-benar telah matang secara fisik maupun psikis (rohani), atau harus sudah siap secara jasmani maupun rohani, sesuai dengan yang tertera dalam pengertian perkawinan itu sendiri "perkawinan adalah ikatan lahir batin antara seorang pria dengan seorang wanita". Berkenaan dengan asas kematangan ini, salah satu standard yang digunakan adalah penetapan usia kawin (nikah). ${ }^{25}$

Keenam, Asas Memperbaiki Derajat Kaum Wanita, undang-undang perkawinan Islam pada umumnya memperjelas dan mempertegas hak-hak yang harus diperoleh kaum perempuan (isteri/ibu) dibalik pencantuman kewajiban-kewajiban yang dibebankan kepada kaum laki-laki (suami/ayah). ${ }^{26}$

Ketujuh, Asas Legalitas, asas lain dalam hukum (undang-undang) perkawinan yang tidak kalah penting terutama di era hukum tertulis dengan kodifikasi hukum sebagai ciri utamanya ialah asas legalitas, yang pada intinya mengajarkan bahwa setiap perkawinan wajib dicatat oleh petugas (pejabat) yang berwenang. ${ }^{27}$ Kedelapan, Asas selektivitas, asas ini dirumuskan dalam beberapa larangan

\footnotetext{
${ }^{24}$ Muhammad Amin Summa, Hukum Keluarga Islam Di Dunia Islam (Jakarta: PT Raja Graffindo Persada, 2005), hlm. 182

${ }^{25}$ Ibid, hlm. 183

${ }^{26}$ Ibid. hlm. 185

${ }^{27}$ Ibid. hlm. 188
} 
perkawinan, dengan siapa seseorang boleh melakukan perkawinan, dan dengan siapa pula dia dilarang (tidak boleh) menikah. ${ }^{28}$

\section{Hukum, Syarat dan Rukun Perkawinan}

Sebagian ulama mengatakan hukum perkawinan adalah fardlu kifayah, seperti halnya jihad dan shalat jenazah. Artinya, hukum fardlu kifayah bagi perkawinan menunjukkan jika telah ada yang melakukannya, maka gugurlah kewajiban bagi yang lain. Sedangkan sebagian Hanafiyyah mengatakan bahwa perkawinan itu wajib bagi yang mampu. Ini sama halnya dengan menjawab salam. Juga ada yang mengatakan wajib 'ain dalam pengamalannya yang telah ditentukan kewajibannya seperti zakat fitrah dan menyembelih kurban. ${ }^{29}$ Kewajiban ini berdasar pada firman Allah SW'T dalam QS. Al-Nur (24): 32 sebagaimana berikut:

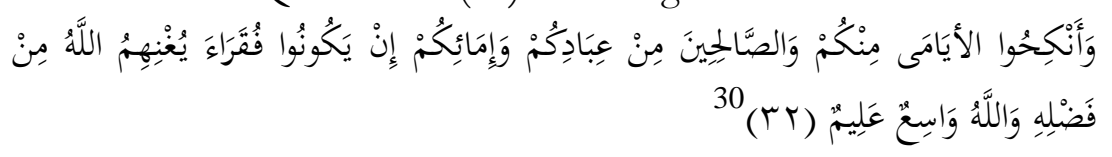

"Dan kawinkanlah orang-orang yang sedirian diantara kamu, dan orang-orang yang layak (berkawin) dari hamba-hamba sahayamu yang lelaki dan hamba-hamba sahayamu yang perempuan. jika mereka miskin Allah akan memampukan mereka dengan kurniaNya. dan Allah Maha Luas (pemberian-Nya) lagi Maha mengetahui."

Bagi ulama yang mengatakan wajib 'ain dalam pengamalannya berdasarkan pula pada perintah-perintah yang telah ada pada bab perkawinan seperti halnya dalil-dalil diatas, akan tetapi alasannya dikatakan perkawinan itu hukumnya wajib 'ain dalam pengamalannya adalah bahwa sighat amr itu pastilah mempunyai qorinab yang menunjukkan wajib dan sunnah, qorinah tersebut adalah makna طلب dan دعاء دعاء maka menunjukkan sunnah, sedangkan kedua makna itu ada pada sighat amr pada dalil-dalil yang menunjukkan perkawinan tersebut, oleh karena itu hal inilah yang dijadikan alasan penetapan hukum wajib 'ain dalam pengamalannya, jika yang dikehendaki oleh Allah adalah wajib maka tidak mendapatkan tanggungan dan jika yang dikehendaki oleh Allah adalah sunnah maka mendapatkan pahala. ${ }^{31}$

\footnotetext{
${ }^{28}$ Ibid.

${ }^{29}$ Ibid, hlm. 229

30 Al-Qur'an danTafsirannya (Jakarta: Lentera Abadi, 2010), Jus 10, hlm. 100

31 'Alau al-Din al-Kasani, Badai' Sanai' (Maktabah Syamilah), Jus 2, hlm. 229
} 
Dalam perkawinan menurut Undang-Undang tentang perkawinan yang berlaku di Indonesia terdapat beberapa rukun dan syarat dalam perkawinan. Rukun-rukun perkawinan melipti: calon suami, calon isteri, wali nikah, dua orang saksi dan ijab kabul. ${ }^{32}$

Sedangkan syarat-syarat perkawinan antara lain adalah:

1. Perkawinan didasarkan atas persetujuan kedua calon mempelai.

2. Untuk melangsungkan perkawinan seorang yang belum mencapai umur 21 (dua puluh satu) tahun harus mendapat izin kedua orang tua.

3. Dalam hal seorang dari kedua orang tua meninggal dunia atau dalam keadaan tidak mampu menyatakan kehendaknya, maka izin yang dimaksud ayat (2) pasal ini cukup diperoleh dari orang tua yang masih hidup atau dari orang tua yang mampu menyatakan kehendaknya.

4. Dalam hal kedua orang tua telah meninggal dunia atau dalam keadaan tidak mampu untuk menyatakan kehendaknya, maka izin diperoleh dari wali orang yang memelihara atau keluarga yang mempunyai hubungan darah dalam garis keturunan lurus ke atas selama mereka masih hidup dan dalam keadaan menyatakan kehendaknya.

5. Dalam hal ada perbedaan antara orang-orang yang dimaksud dalam ayat (2), (3) dan (4) pasal ini, atau salah seorang atau lebih diantara mereka tidak menyatakan pendapatnya, maka Pengadilan dalam daerah tempat tinggal orang yang akan melangsungkan perkawinan atas permintaan orang tersebut dapat memberikan ijin setelah lebih dahulu mendengar orangorang yang tersebut dalam ayat (2), (3) dan (4) dalam pasal ini.

6. Ketentuan tersebut ayat (1) sampai dengan ayat (5) pasal ini berlaku sepanjang hukun masing-masing agamanya dan kepercayaannya itu dari yang bersangkutan tidak menentukan lain.33

7. Perkawinan hanya diizinkan bila piha pria mencapai umur 19 (sembilan belas) tahun dan pihak wanita sudah mencapai usia 16 (enam belas) tahun.

8. Dalam hal penyimpangan dalam ayat (1) pasal ini dapat minta dispensasi kepada Pengadilan atau pejabat lain yang diminta oleh kedua orang tua pihak pria atau pihak wanita.

\footnotetext{
32 Kompilasi Hukum Islam, (Surabaya: Arkola), Pasal 14, hlm. 183

${ }^{33}$ Undang-Undang Nomor 1 Tabun 1974 Tentang Perkawinan (Surabaya: Arkola), Pasal 6, hlm. 8
} 
9. Ketentuan-ketentuan mengenai keadaan salah seorang atau kedua orang tua tersebut pasal 6 ayat (3) dan (4) Undangundang ini, berlaku juga dalam hal permintaan dispensasi tersebut ayat (2) pasal ini dengan tidak mengurangi yang dimaksud dalam pasal 6 ayat (6). ${ }^{34}$

10.Perkawinan dilarang antara dua orang yang:

a) Berhubungan darah dalan garis keturunan lurus kebawah atau keatas;

b) Berhubungan darah dalam garis keturunan menyamping yaitu antara saudara, antara seorang dengan seorang saudara orang tua dan antara seorang dengan saudara neneknya;

c) Berhubungan semenda, yaitu mertua, anak tiri, menantu dan ibu/bapak tiri;

d) Berhubungan susuan, anak susuan, saudara dan bibi/paman susuan;

e) Berhubungan saudara dengan isteri atau sebagai bibi atau kemenakan dari isteri, dalam hal seorang suami beristeri lebih dari seorang;

f) Mempunyai hubungan yang oleh agamanya atau praturan lain yang berlaku dilarang kawin. ${ }^{35}$

11.Seorang yang terikat tali perkawinan dengan orang lain tidak dapat kawin lagi, kecuali dalam hal yang tersebut dalam Pasal 3 ayat (2) dan dalam Pasal 4 Undang-undang ini. ${ }^{36}$

12. Apabila suami dan istri yang telah cerai kawin lagi satu dengan yang lain dan bercerai lagi untuk kedua kalinya, maka diantara mereka tidak boleh dilangsungkan perkawinan lagi, sepanjang hukum, masing-masing agama dan kepercayaan itu dari yang bersangkutan tidak menentukan lain.37

13.Bagi seorang yang putus perkawinannya berlaku jangka waktu tunggu.

14.Tenggang waktu jangka waktu tunggu tersebut ayat (1) akan diatur dalam Peraturan Pemerintah lebih lanjut.38

15.Tata cara perkawinan diatur dalam peraturan perundangundangan tersendiri. ${ }^{39}$

${ }^{34}$ Ibid, Pasal 7, hlm. 8

${ }^{35}$ Ibid, Pasal 8, hlm. 9

${ }^{36}$ Ibid, Pasal 9, hlm. 9

${ }^{37}$ Ibid, Pasal 10, hlm. 9

${ }^{38}$ Ibid, Pasal 11, hlm. 9

${ }^{39}$ Ibid, Pasal 12, hlm. 9 
Sedangkan mengenai syarat perkawinan menurut para ulama, ulama Hanafiyah membaginya menjadi empat macam, yaitu:

1. Syuruth al-in'iqad, ${ }^{40}$ yaitu syarat yang menentukan terlaksananya suatu akad perkawinan. Karena kelangsungan perkawinan tergantung kepada akad, maka syarat disini adalah syarat yang harus dipenuhi karena ia berkenaan dengan akad itu sendiri. Bila syarat-syarat itu tertinggal, maka akad perkawinan disepakati batalnya. Syarat ini berhubungan dengan dua hal, syarat mempelai dan syarat ijab kabul. Syarat-syarat yang berhubungan dengan mempelai yaitu:

a. Pihak-pihak yang melakukan akad memiliki kemampuan untuk bertindak hukum. Khusus bagi mempelai wanita terdapat syarat tambahan, antara lain:

1) Benar-benar wanita;

2) Bukan wanita yang dilarang kawin dengan calon pengantin laki-laki.

b. Bisa mendengarkan ucapan pihak lain.

Sedangkan syarat-syarat ijab kabul diantaranya:

a. Satu majelis ketika kedua orang yang melakukan akad hadir;

b. Sesuai antara kabul dengan ijab;

c. Tetapnya orang yang ijab atas ijabannya;

d. Selesai seketika.

2. Syuruth al-shibhah, ${ }^{41}$ yaitu sesuatu yang keberadaannya menentukan dalam perkawinan. Syarat tersebut harus dipenuhi untuk dapat menimbulkan akibat hukum, dalam arti bila syarat tersebut tidak terpenuhi, maka perkawinan itu tidak sah, antara lain:

a. Calon isteri bukan wanita yang haram untuk dinikahi;

b. Sighotnya untuk selamanya;

c. Penyaksian;

d. Persetujuan dan kehendak sendiri;

e. Jelasnya kedua calon mempelai;

f. Tidak dalam keadaan ihram umrah atau haji;

g. Adanya mahar;

h. Tidak ada perselingkuhan yang disembunyikan;

i. Salah satu calon mempelai atau keduanya tidak ada penyakit yang dikhawatirkan;

40 Muhammad Amin Ibn Abidin, Al-Dur al-Mukhtar (Beirut: Dar al-Fikr), Jus 2, hlm. $366,367,372$

'Alau al-Din al-Kasani, Badai' Sanai' (Beirut: Dar al-Fikr), Jus 2, hlm. 232

41 Muhammad Amin Ibn Abidin, Al-Dur al-Mukbtar (Beirut: Dar al-Fikr), Jus 2, hlm. 373-379, 835

'Alau al-Din al-kasani, Badai' Sanai' (Beirut: Dar al-Fikr), Jus 2, hlm. 351-357 
j. Wali.

3. Syuruth al-Nafadr, ${ }^{42}$ yaitu syarat yang menentukan kelangsungan suatu perkawinan. Akibat hukum setelah berlangsung dan sahnya perkawinan tergantung kepada adanya syarat-syarat itu tidak terpenuhi menyebabkan fasidnya perkawinan, antara lain:

a. Keduanya benar-benar mampu melaksanakan perkawinan serta berakal, baligh dan merdeka;

b. Calon mempelai laki-laki harus cerdas (mengerti baik buruknya) perkawinan;

c. Bukanlah wali jauh jika ada wali dekat (jika perkawinannya yang menggunakan wali);

d. Tidak adanya perbedaan diantara wakil dengan yang diwakilinya;

e. Orang yang akad tidaklah berlebihan.

4. Syuruth al-Luzum, ${ }^{43}$ yaitu syarat yang menentukan kepastian suatu perkawinan dalam arti tergantung kepadanya kelanjutan berlangsungnya suatu perkawinan sehingga dengan telah terdapatnya syarat tersebut tidak mungkin perkawinan yang sudah berlangsung itu dibatalkan. Hal ini berarti selama syarat itu belum terpenuhi perkawinan dapat dibatalkan, antara lain:

a. Adanya wali yang menikahkan bagi yang tidak mampu melaksanakan perkawinan seperti orang gila dan lain-lain;

b. Calon mempelai laki-laki haruslah sekufu dengan calon mempelai wanita yang berakal, baligh serta merdeka yang menikahkan dirinya sendiri tanpa wali dengan mahar mitsil;

c. Maharnya melebihi mahar mitsil ketika wanita yang berakal, baligh serta merdeka menikah dengan laki-laki yang tidak sekufu;

d. Tidak adanya cacat bagi calon suami yang bisa menjadikan calon isteri tidak ridha padanya, contohnya lemah syahwat.

\section{Persetujuan Calon Mempelai Wanita Dalam Perkawinan}

Kewalian dalam perkawinan menurut Imam Kamaluddin Muhammad ibn Abdul Wahid, salah satu ulama Hanafiyah, dalam kitab Fath al-Qadir ada dua macam, yaitu kewalian nadb atau istibbab dan kewalian ijbar. $^{44}$ Kewalian nadb atau istibbab yaitu kewalian terhadap perempuan baligh yang berakal, baik perawan ataupun janda. Sedangkan

42 Muhammad Amin Ibn Abidin, Al-Dur al-Mukhtar (Beirut: Dar al-Fikr), Jus 2, hlm. 379

'Alau al-Din al-Kasani, Badai' Sanai' (Beirut: Dar al-Fikr), Jus 2, hlm. 233

43 'Alau al-Din al-Kasani, Badai' sanai' (Beirut: Dar al-Fikr), Jus 2, hlm. 315-322

${ }^{44}$ Kamaluddin Muhammad Ibn Abdul Wahid (Ibn Himam), Fath al-Qadir (Maktabah Syamilah), Juz 6, hlm. 459 
kewalian ijbar yaitu kewalian terhadap perempuan yang belum baligh, baik perawan ataupun janda. Begitu juga terhadap perempuan yang baligh yang kurang akalnya dan wanita yang dijadikan budak kewalian yang berlaku adalah kewalian ijbar. ${ }^{45}$

Adapun dalam kitab Hanafiyyah lain, Badai' Sanai' karya Imam 'Alau al-Din al-Kasani mencantumkan kewalian terbagi menjadi dua macam, yaitu kewalian khatm atau ijab atau istibdad dan kewalian nadb. ${ }^{46}$ Kewalian yang pertama (khatm atau ijab atau istibdad) ketentuannya meliputi: anak-anak, pria dan wanita dewasa yang tidak berakal, anak perempuan perawan dan janda. Ketentuan kewalian ini tidak meliputi terhadap pria dan wanita dewasa yang berakal. ${ }^{47}$

Dalam kitab Radd al-Mukhtar dikatakan bahwa kewalian itu ada dua yakni kewalian nadb, dan kewalian ijbar. Kewalian nadb adalah kewalian terhadap wanita yang berakal serta baligh meskipun itu gadis, kewalian ijbar adalah kewalian terhadap wanita yang berakal, baligh meskipun itu seorang janda. Kewalian itu menjadi syarat shibhah bagi wanita yang belum dewasa, orang gila serta budak, tidak bagi wanita yang sudah dewasa, Oleh karena itu sah nikahnya seorang wanita yang berakal, baligh (dewasa) tanpa restu oleh seorang walinya. Hal ini dikarenakan bagi setiap orang yang bisa bertransaksi ekonomi sendiri maka dia berhak atas apa yang ada pada dirinya termasuk menikahkan dirinya sendiri, dan apabila dia tidak mampu untuk bertransaksi ekonomi sendiri maka dia tidak bisa berbuat atas dirinya sendiri melainkan walinya yang berhak atas dirinya. ${ }^{48}$

Dalam kitab Tabyin al Haqaiq, Imam Fakhruddin Usman mengutip sama dengan apa yang ada dalam kitab Radd al-Mukbtar pernyataan Imam Abu Hanifah yang mengatakan bahwa "sah nikahnya wanita merdeka, berakal serta baligh tanpa restu seorang wali", pendapat ini juga dilontarkan oleh Abi Yusuf, awalnya Abi Yusuf tidak mengatakan hal demikian, akan tetapi beliau berpendapat bahwa "wanita yang baligh, berakal serta merdeka tidaklah sah menikah kecuali dengan restu walinya", kemudian beliau mencabut atau mengklarifikasi pernyataan beliau tersebut dengan mengatakan bahwa "wanita yang sudah baligh, berakal serta merdeka (dewasa) boleh menikah tanpa restu walinya jika calon suaminya sekufu (sepadan)", jika calon suaminya tidak sepadan dengan wanita tersebut maka sudah barang tentu tidaklah boleh menikah tanpa restu walinya. Kemudian lebih lanjut beliau mengklarifikasinya

\footnotetext{
45 Ibid.

46 'Alau al-Din al-Kasani, Badai' Sanai' (Maktabah Syamilah), jus 2 hlm. 241

${ }^{47}$ Ibid.

${ }^{48}$ Muhammad Amin Ibn Abidin, Radd al-Mukbtar (Maktabah Syamilah), Jus 9, hlm. 342
} 
kembali dengan pernyataan beliau selanjutnya yang mengatakan bahwa "wanita yang dewasa boleh menikahkan dirinya sendiri tanpa adanya restu dari walinya baik calon suaminya itu sepadan ataupun tidak sepadan". ${ }^{49}$

Lebih lanjut dalam kitab Tabyin al-Haqaiq, Imam Fakhruddin Usman mengatakan bahwa yang menjadi dalil dari pernyataan-pernyataan Hanafiyah diatas adalah:

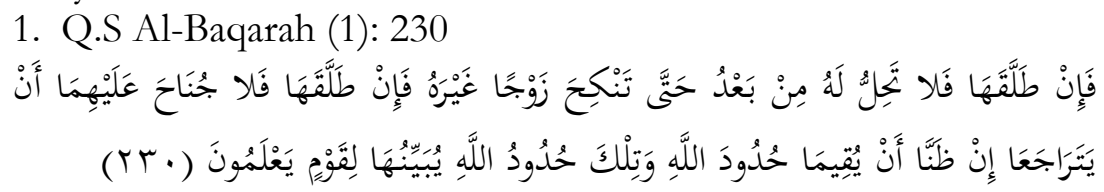

"Kemudian jika si suami mentalaknya (sesudah Talak yang kedua), Maka perempuan itu tidak lagi halal baginya hingga Dia kawin dengan suami yang lain. kemudian jika suami yang lain itu menceraikannya, Maka tidak ada dosa bagi keduanya (bekas suami pertama dan isteri) untuk kawin kembali jika keduanya berpendapat akan dapat menjalankan hukum-hukum Allah. Itulah hukum-hukum Allah, diterangkan-Nya kepada kaum yang (mau) mengetahui." ${ }^{50}$

2. QS. Al-Baqarah (1): 232

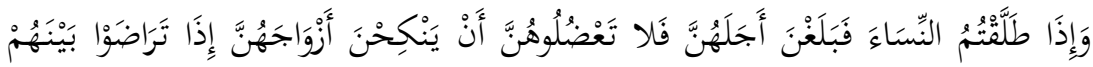

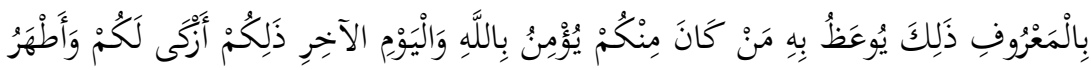

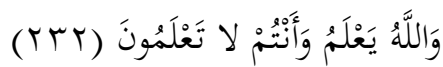

"Apabila kamu mentalak isteri-isterimu, lalu habis masa iddahnya, Maka janganlah kamu (para wali) menghalangi mereka kawin lagi dengan bakal suaminya[146], apabila telah terdapat kerelaan di antara mereka dengan cara yang ma'ruf. Itulah yang dinasehatkan kepada orang-orang yang beriman di antara kamu kepada Allah dan hari kemudian. itu lebih baik bagimu dan lebih suci. Allah mengetahui, sedang kamu tidak mengetahui."

[146] Kawin lagi dengan bekas suami atau dengan laki-laki yang lain. ${ }^{51}$

3. QS. Al-Baqarah (1): 234

\footnotetext{
${ }^{49}$ Fakhruddin Usman, Tabyin al-Haqaiq (Maktabah Syamilah), Jus 2, hlm. 117

50 Al-Qur'an danTafsirannya, (Jakarta: Lentera Abadi, 2010), jus 1, hlm. 336

${ }^{51}$ Ibid.
} 


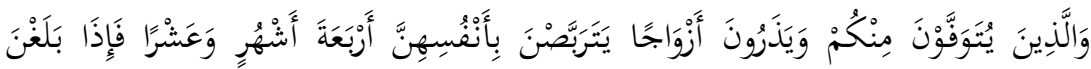

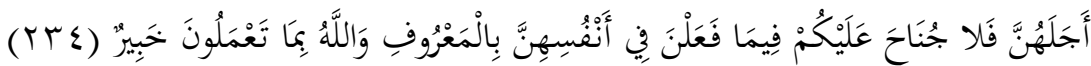
"Orang-orang yang meninggal dunia di antaramu dengan meninggalkan isteri-isteri (hendaklah Para isteri itu) menangguhkan dirinya (ber'iddah) empat bulan sepuluh hari. kemudian apabila telah habis 'iddahnya, Maka tiada dosa bagimu (para wali) membiarkan mereka berbuat terhadap diri mereka menurut yang patut. Allah mengetahui apa yang kamu perbuat." 52

Ayat-ayat diatas menjelaskan bahwa menikah itu sah dengan hanya حتى تنكح mendengarkan ucapan wanita, hal ini sesuai dengan lafadz (hingga dia kawin) pada QS. Al-Baqarah (1): 230 dan lafadz ان ينكحن نئ (mereka kawin lagi) pada QS. Al-Baqarah (1): 232. Hal ini telah jelas bahwa sesungguhnya menikah itu adalah sesuatu yang keluar atau yang dikehendaki oleh wanita tersebut. Adapun pada lafadz ان يتراجعا (untuk kawin kembali) QS. Al-Baqarah (1): 230 dan pada lafadz فيما فعلن (membiarkan mereka berbuat) QS. Al-Baqarah (1): 234 adalah jelas menerangkan tentang wanita itu berhak melakukan (perkawinan) ataupun tidak melakukannya sesuai dengan apa yang dikehendakinya. ${ }^{53}$

Pada dasarnya status kewalian ijab ini menurut Imam Hanafi hanya memliki daya otoritasi terhadap anak-anak, baik laki-laki ataupun perempuan. Yang dimaksud dengan anak-anak di sini adalah seorang yang belum menyentuh status baligh. Ini menunjukkan bahwa status keperawanan atau janda juga masuk di dalamnya, selama belum baligh. Ini yang membedakan dengan orang dewasa, karena pada laki-laki dan perempuan dewasa yang menjadi ukuran adalah akal sehat. Maksudnya, apabila akal orang dewasa kurang sehat, maka dia masuk ke dalam kewalian ijab. Begitu juga sebaliknya, apabila akal tersebut sehat, maka dia masuk ke dalam kewalian nadb. ${ }^{54}$

Adapun dalam permasalahan status wali perkawinan, menurut Imam 'Alau al-Din al-Kasani, ayah dan kakek tidak memiliki otoritas untuk mengawinkan perawan dewasa tanpa adanya persetujuan darinya. Ini juga berlaku pada wali janda dewasa. Hal ini dikarenakan janda dewasa lebih mengetahui kemaslahatan-kemaslahatan perkawinan daripada walinya. Janda dewasa telah memiliki pengalaman bergaul

\footnotetext{
52 Al-Qur'an dan Tafsirannya (Jakarta: Lentera Abadi, 2010), Jus 1, hlm. 350

53 Ibid.

54 'Alau al-Din al-Kasani, Badai' Sanai' (Maktabah Syamilah), jus 2 hlm. 241
} 
dengan laki-laki. Dengan demikian, kewalian wajib atas dirinya menjadi gugur. $^{55}$

Imam Syamsuddin Abu Bakar Muhammad Bin abi Sahal alSyarakhsi menyatakan jika seorang wali menyampaikan kepada anak perawannya yang telah baligh tentang maksudnya untuk mengawinkannya, sedangkan anak tersebut tidak merespons (tidak mengiyakan ataupun menolak maksud tersebut), maka itu adalah bentuk persetujuan. Dengan arti lain bahwa dia setuju untuk dikawinkan. Namun apabila secara terang-terangan dia menolak maksud itu, maka wali tidak memiliki daya otoritasi untuk memaksanya. Dengan demikian, wali tidak berhak untuk melangsungkan akad nikah. ${ }^{56}$

\section{Maqhashid Nikah Dalam Persetujuan Calon Mempelai Wanita}

Dalam merumuskan sebuah hukum tentunya para ulama pasti mempertimbangkan aspek maslahah serta mafsadah yang akan dapat diambil dari produk hukum yang akan dibuat, proses pertimbangan tersebut tidak boleh bertentangan dengan Al-Qur'an serta Hadist selain itu juga harus sejalan dengan prinsip dan tujuan syariat islam atau Maqhashid syar'iyyah.

Definisi Maqhashid syar'iyyah secara umum adalah tujuan-tujuan akhir yang harus terrealisasi dengan diaplikasikannya syariat. Tujun ini Meliputi keseluruhan Aspek Syariat yang pada akhirnya seluruhnya bermuara untuk kebaikan umat manusia baik di dunia maupun di akhirat. ${ }^{57}$

Tujuan pokok Maqhashid syar'iyyah dibagi menjadi 6 yaitu:

1. Hifdz al-din, memelihara agama.

Memelihara agama, tujuan Hifdz al-din pembebanan syariat yang menjamin tegaknya agama dan keyakinan. Salah satu bentuknya adalah perintah untuk beribadah kepada Allah. ${ }^{58}$

2. Hifdzal-nafs, memelihara kelangsungan hidup (Jiwa).

Adalah bentuk pembebanan syariat dalam rangka menjamin keselamatan jiwa dan raga. Agama mengharamkan membunuh tanpa alasan yang dibenarkan syariat serta pelakunya dijatuhi hukuman qishas. ${ }^{59}$

\footnotetext{
${ }^{55}$ Ibid, hlm. 241-242

${ }^{56}$ Syamsuddin Abu Bakar Muhammad Bin Abi Sahal al-Sarakhsi, Al Mabsuth Lil Sarakbsi (Maktabah Syamilah), jus 5, hlm. 2

57 Abd. Holik., Ringkasan Disertasi "Usia Dewasa Perkawinan Dalam Hukum Positif di Indonesia Perspektif Maqasid Shari’ab”, (Surabaya: Pascasarjana UIN Sunan Ampel, 2019) hlm. 10

${ }^{58}$ Ibid. hlm 11

${ }^{59}$ Ibid
} 
3. Hifdr al-aql, memelihara akal.

Adalah pembebanan syariat daam rangka menjamin akal sehat manusia, maka agama mengharamkan minum-minuman keras. $^{60}$

4. Hifdz al-nasl, memelihara keturunan.

Maksudnya adalah dalam rangka menjamin keturunan manusia tetap lestari, maka agama mengharamkan zina dan bagi yang melanggar akan didera. ${ }^{61}$

5. Hifdz al-mal, memelihara harta.

Pembebanan syariat dalam rangka menjamin kepemilikan harta benda. Lewat harta kemaslahatan dunia akan tercapai.

6. Hifdz al- Ird, menjaga kehormatan.

maksudnya bahwa syariat itu ada untuk menjamin serta memlihara kehormatan, maka agama mewajibkan menghukum orang yang zina. ${ }^{62}$

Jamal al-Din 'Atiyah, seorang ulama kontemporer membagi Maqhasid dalam pernikahan menjadi tujuh, yaitu: Pertama, Mengatur hubungan laki-laki dan perempuan. Kedua, Menjaga Keturunan. Ketiga, Mewujudkan rasa sakinah mawaddah wa rahmah. Keempat, Menjaga kejelasan garis keturunan (nasab). Kelima, menjaga agama dalam kehidupan keluarga. Keenam, mengatur aspek-aspek dasar keluarga, diantaranya: langgengnya perkawinan, kejelasan hak dan kewajiban suami-istri, musyawarah dalam setiap keputusan penting, mengikuti setiap aturan syariat dalam menjalankan perkawinan, adanya aturan tentang hubungan antara suami-istri dan anak-anaknya, mengatur hubungan antara keluarga besar suami-istri dan tetangga. Keenam, Mangatur aspek ekonomi keluarga. ${ }^{63}$

Berkaitan dengan Maqhashid nikah dalam persetujuan calon mempelai wanita sebelum menikah, seperti yang dijelaskan dengan teoriteori di atas bahwa persetujuan wanita itu sesuai dengan Maqhashid syariah Hifdz al-nasl dan Hifdz al-Ird. Bentuk persesuaian ini dalam aspek Hifdzal-nasl bahwa persetujaun calon mempelai wanita adalah sebab terjadinya suatu perkawinan, dan apabila perkawinan tetap dilakukan tanpa adanya persetujuan calon mempelai wanita ataupun karena terpaksa, maka kemungkinan besar perkawinan tersebut tidak akan

\footnotetext{
${ }^{60}$ Ibid

${ }^{61}$ Ibid

${ }^{62}$ Ibid.

${ }^{63}$ Jamal al-Din 'Atiyyah, Naḥw Taf'il Maqashid al-shariah (Damaskus: Dar al-Fikr, 2003), hlm. 149-154
} 
bertahan dan akan mengalami perceraian, dan korban dalam perceraian itu adalah istri dan anak (keturunan).

Sedangakan dalam Aspek Hifdzal-Ird bahwa persetujuan calon mempelai wanita adalah indikasi adanya perasaan menerima serta rasa kasih sayang kepada calon suaminya, sehingga dalam menjalani perkawinan istri akan senantiasa menjaga kehormatan suami. Disamping itu akan terwujud keluarga yang sakinah, mawaddah warahmah sesuai dengan tujuan perkawinan.

\section{Penutup}

Dari pembahasan di atas dapat diambil kesimpulan bahwa Persetujuan calon mempelai wanita dalam memutuskan pernikahannya adalah sah, dan bersesuaian dengan Maqhashid syariah Hifdzal-nasl dan Hifdz.al-Ird serta tujuan perkawinan dalam membentuk keluarga sakinah, mawaddah warahmah. 


\section{DAFTAR PUSTAKA}

Abidin, Muhammad Amin Ibn. Jus 2, Al-Dur al-Mukhtar, Beirut: Dar alFikr.

Abidin, Muhammad Amin Ibn. Jus 6, Al-Dur al-Mukhtar, Beirut: Dar alFikr.

al-Sarakhsi, Syamsuddin Abu Bakar Muhammad Bin Abi Sahal. jus 5, Al Mabsuth Lil Sarakhsi (Maktabah Syamilah).

al-Asqalani, Ibnu Hajar. t.th. Bulughul Maram, Mesir: al-Matba'ah Salafiyyah.

Ali, Atabik. cetakan 9, Kamus Kontemporer Arab Indonesia, Yogyakarta: Multi Karya Grafika.

Al-Baihaqi, Ahmad Ibn Husein. Jus 7, Sunan al-Baihaqi al-Kubra (Maktabah Syamilah)

Al-Bukhari. Juz 6, Sahih Al- Bukhori, Beirut: Dar al-Fikr al-Kasani, 'Alau al-Din. Jus 2, Badai' Sanai' (Maktabah Syamilah) Al-Qur'an danTafsirannya, Juz 2, 2010. Jakarta: Lentera Abadi.

Holik, Abd. 2019, Ringkasan Disertasi "Usia Dewasa Perkawinan Dalam Hukum Positif di Indonesia Perspektif Maqasid Shari'ah", Surabaya: Pascasarjana UIN Sunan Ampel.

Syarifuddin, Amir. 2006. Hukum Perkawinan Islam di Indonesia: Antara

Fiqh Munakahat dan Undang-Undang Perkawinan, Jakarta:

Prenada Media.

Kompilasi Hukum Islam

Mughniyah, Muhammad Jawad. 2000, Fiqh Lima Mazhab, Ja'fari, Hanafi, Maliki, Syafi'I, Hambali, Jakarta: Lentera.

Nidham, Syaikh. Jus 1, Al-Fatawa al-Hindiyah (Maktabah Syamilah).

Nuruddin, Amiur dkk. 2004, Hukum Perdata Islam, Jakarta: Prenada Media.

Usman, Fakhruddin. Jus 2, Tabyin al-Haqaiq (Maktabah Syamilah).

Undang-Undang Nomor 1 Tahun 1974 Tentang Perkawinan, t.th. Surabaya: Arkola.

Rofiq, Ahmad. 1997, Hukum Islam di Indonesia, Jakarta: Raja Grafindo Persada.

Summa, Muhammad Amin. 2005, Hukum Keluarga Islam Di Dunia Islam, Jakarta: PT Raja Graffindo Persada.

Wahid, Kamaluddin Muhammad Ibn Abdul. jus 6, Fath al-Qadir (Maktabah Syamilah)

Wahid, Kamaluddin Muhammad Ibn Abdul. jus 3, Fath al-Qadir (Maktabah Syamilah)

Zuhayli, Wahbah. Juz 9, 1997. Al-Fiqh al-Islami Wa Adillatuhu, Beirut: Dar al-Fikr. 
Husein, Muhammad. 2001, Fiqh Perempuan, Yogyakarta LKiS.

'Atiyyah, Jamal al-Din. 2003, Nah\}w Tafil Maqashid al-shariah, Damaskus: Dar al-Fikr. 